\title{
Changing Soil Fertility in Chernozems of Western Siberia as a Result of Prolonged Plowing
}

\author{
Eremina Diana \\ Department of Mathematics and Computer Science, Federal \\ State Budgetary Educational \\ Institution of Higher Education \\ «Northern Trans-Ural State Agricultural University» \\ Tyumen, Russia \\ soil-tyumen@yandex.ru
}

\author{
Selyukova Galina \\ Department of Mathematics and Computer Science, Federal \\ State Budgetary Educational \\ Institution of Higher Education \\ «Northern Trans-Ural State Agricultural University» \\ Tyumen, Russia \\ soil-tyumen@yandex.ru
}

\author{
Selyukiva Svetlana \\ Department of Mathematics and Computer Science, \\ Federal State Budgetary Educational \\ Institution of Higher Education \\ «Northern Trans-Ural State Agricultural University» \\ Tyumen, Russia \\ soil-tyumen@yandex.ru
}

\begin{abstract}
Agriculture in Western Siberia is a dynamically developing sector that has its firm foundation in results of agricultural research. Plowing-up of high-fertility soils led to changes in the direction of soil formation. It reflected in their quality and productivity. Vastly increased anthropogenic burden had negative impact on humus formation and acid-base characteristic of the croplands. To prevent deterioration of quality and develop measures for its reclamation, a complex of multi-year research is necessary. Its goal is monitoring the dynamics of humus state, acidity and composition of arable chernozem cations in Western Siberia. The research was conducted in the Northern Trans-Ural State Agricultural University, at a station located in Tobol-Ishim interstream area of the eastern periphery of the Trans-Uralian Plateau. The multiyear research led to establishing that plowing of leached chernozems leads to increased humus mineralization that has a negative impact on the state of the humus. In 40 years, the loss of soil organics in the $0-20 \mathrm{~cm}$ layer amounted to $54 \mathrm{t} / \mathrm{ha}$, of which 9 tonnes migrated deeper into the soil profile. Increased biogenic depletion and leak of calcium and magnesium facilitated acidification of the arable black soil: during the years of the studies, exchangeable acidity increased from 5.5 to 5.0 units, hydrolytic acidity increased from 3.7 to $4.6 \mathrm{mmol} / \mathrm{kg}$. Anthropogenic changes in fertility of arable black soil are seen throughout the humus layer.
\end{abstract}

Keywords - anthropogenic soil formation, Western Siberia, humus state, acid-base characteristic, humus mineralization.

\section{INTRODUCTION}

Agriculture undergoes active development in Western Siberia despite unfavorable climate $[1,2]$. Development of the agricultural sector in Trans-Ural is facilitated by exploratory work of scientists who during the last decades produced new cultivars capable of high yields on low fertility soils under short vegetation period conditions [3]. New breeds of animals, conditioned for this region have been bred [4]. Introduction of digital technologies into agriculture made it possible to apply IT and mathematical modeling methods to take into account a multitude of factors [5, 6]. Elaborate study of soil formation specifics in Siberia and development of modeling software determined further development of precise agriculture in the region. It gave farmers an ability to create artificial potting soils with predefined fertility parameters in the regions where the topsoil is not appropriate for agriculture [7, 8]

Such an active development of agricultural technologies led to increased anthropogenic load onto the fertile soils of Western Siberia. It had a negative impact on the fertility indicators, as the topsoil in the region is less resistant to mechanical treatment and changes in nutrient status. Consequences of the active use of fertile soils under plow are reflected in changes in the qualitative composition of humus and some physical and chemical properties $[9,10]$.

Analysis of transformation and evolution of soils that are involved in agriculture is traditionally in the center of attention of genetic soil science and has an important applied significance for agricultural environmental optimization and adaptation of the modern agricultural systems to the conditions of a certain agricultural landscape [11]. Rationale for the studies of black soils of Western Siberia is determined by prevalence of young (compared to the European Russia) topsoil that has only recently found use in agriculture. Modern intensive use of plowed fields with clear violation of the agricultural system, as well as local change of agricultural landscapes led to appearance of agrochernozems pertaining to the same subtype and kind of soil taxonomically, but significantly differing from each other by their fertility indicators. 
With appearance of various types of soil degradation, often those unusual for the natural soil formation process, accumulation of its consequences for many years and acute systemic crisis in land use make the studies of agrogenic dynamics of fertility the most important features for determination of agro-environmental condition of the plowed chernozem.

Knowledge of speed and direction of anthropogenic fertility changes significantly simplifies prediction of modern development, functional quality and environmental condition of plowed chernozems. Developmental regularities identified in chernozem formation help in their agro-ecological typification and lay a foundation for modeling environmentally safe land use in the forest-steppe zone of Trans-Ural.

Research objective: Identification of fertility changes in leached chernozems soils of Western Siberia.

\section{SUBJECTS AND METHODS}

The research has been performed at the station of the Department of Soil Science and Agricultural Chemistry of the Northern Trans-Ural State Agricultural University; the station was founded on leached chernozem in 1968 (Voronic Chernozems WRB, 2014). The station is located $3 \mathrm{~km}$ from the village of Michurino in Zavodoukovsky district of Tyumen oblast, in the northern forest-steppe with kolkis relief of Tobol-Ishim interfluve, at the eastern outskirts of the TransUral Plateau. Soil forming rocks are clay-silt loess-like clay loams with a thickness of under $10 \mathrm{~m}$. After taking the samples, one part of the station's territory was plowed and until now has been plowed regularly, while another part is still under the natural vegetation in its virgin soil state.

Subject of research is leached chernozem, rich, of medium thickness, middle loamy, on carbonate loessial loam with the attributes and properties typical for Western Siberia [12]. By its granulometric composition it is of a clay-silt middle loamy type, formed on a middle loamy covering silt. Within the soil profile, there is a redistribution of the silt fraction, whose content starts to consistently increase from the depth of $30 \mathrm{~cm}$, forming a humus-less, carbonate-less horizon B2 with the attribute of illuvial horizon. With respect to the humus horizon, the excess is $8.2-8.5 \%$. The upper part of the profile to the depth of $40 \mathrm{~cm}$ is somewhat different from the underlying beds of the soil-forming mass due to low sand content and high dust content, especially coarse dust. Speaking from the coarse dust content, the parent rock is loess-like. Prevailing fractions within the soil profile as a whole are silt and coarse dust. The humus layer $(\mathrm{A}+\mathrm{AB} 1)$ with a thickness of $57 \mathrm{~cm}$, of which humus-accumulating horizon is $41 \mathrm{~cm}$.

HCI boiling depth is $105 \mathrm{~cm}$. The depth of the BK horizon does not exceed one meter.

On the virgin land, there is vegetation of motley grass associations, where the following plants prevail: Libanotis sibirica (L.); Veronica spicata (L.); Lathyrus pratensis (L.); Phleum pratense (L.); Alopecurus pratensis (L.).
In 1990, 2006 and 2017, the department conducted a repeat examination in both virgin land and plowed land, thus giving an opportunity for a comparison of humus formation under conditions of prolonged plowing.

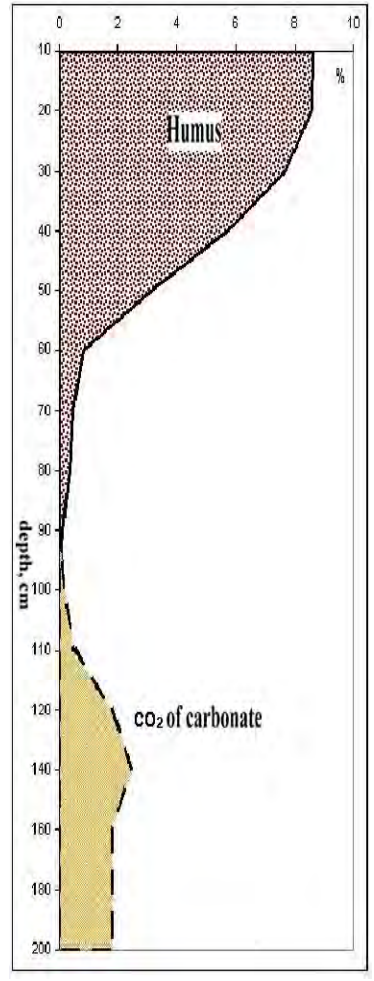

Fig.1. Distribution of humus and $\mathrm{CO} 2$ carbonates through the profile of leached
During the period from 1968 to 1990 , the plowed field was used in a grain-fallow-plow crop rotation (annual grasses, summer wheat, silage corn, summer grain, barley); during that period the soil received 64 $\mathrm{t} / \mathrm{ha}$ of afterharvesting residue and roots and $50 \mathrm{t} / \mathrm{ha}$ of manure. Straw was always removed from the field. During the 19902006 , there was a significant change in the agricultural system: a crop rotation with seeded fallow was used (annual grasses, summer wheat, barley, barley), $63 \mathrm{t} / \mathrm{ha}$ of straw and 50 $\mathrm{t} / \mathrm{ha}$ of afterharvesting residue and roots were plowed in, organic fertilizers in the form of manure were not used. During the 2006-2017, the crop rotation and the main soil management system did not change. Soil management system uses a spreader plow. It has never changed.

The humus content was determined by conversion from organic carbon determined by Turin's method, by multiplying by a factor of 1.724 . Exchange acidity of the soil was determined by a potentiometric method; hydrolytic acidity and the total of exchange bases - by Kappen's method. The results were processed with a dispersion method in Microsoft Excel.

\section{RESULTS}

Soil organics play a leading role in formation of soil fertility, creation of favorable growth and development of favorable conditions for plants and microorganisms. In addition, humus substances facilitate mitigation of negative anthropogenic impact onto the soils and increase sustainability of farming under unfavorable climatic conditions. Modern agrarians many times voiced an opinion that the role of humus decreases when moving to the mineral system of fertilizing. However, it is not so. The role of humus is not only in providing plants with nutrients, but also and even more so in organizing interactions that are more complex. Humus acts as a factor that regulates the biological condition of soil, its capacity for cation exchange, buffer state, hydrophysical properties and structural aggregate state.

When analyzing the soils involved in agriculture, the main attention is paid to agrogenic dynamics of humus, as it has a large influence over agrochemical, agrophysical and 
hydrophysical properties of these soils. High level of dehumification is common for most agricultural chernozems of the Trans-Ural forest-steppe zone. Temporal changes in humus content point at accelerated mineralization of humus after plowing virgin or disused chernozem lands, especially during the first twenty years after plowing, when the rate of dehumification in the plowed layer reaches $0.95 \mathrm{t} /$ year (Table 1). Subsequently, an imbalance appears between formation and dissolution of humus, which may significantly increase the mineralization rates of organics up to 1.2-1.4 t/year. It is a result of changes in soil formation factors $[13,14,15,16]$.

As multi-year research has shown, plowing of virgin chernozem led to a significant reduction in humus reserves. By 1990 they reduced by 22 tonnes and were $459 \mathrm{t} / \mathrm{ha}$ in a one meter layer. Layer-by-layer analysis has shown that the maximum loss of humus appears in the 0-20 cm layer, where its reserves diminished from 224 to $203 \mathrm{t} / \mathrm{ha}$. The least prominent reduction of reserves was observed in the $20-50 \mathrm{~cm}$ layer.

TABLE I. CHANGES IN HUMUS RESERVES IN AGRICULTURAL USE OF LEACHED CHERNOZEM, T/HA

\begin{tabular}{|c|c|c|c|c|}
\hline \multirow{2}{*}{$\begin{array}{c}\text { Depth, } \\
\text { cm }\end{array}$} & \multicolumn{3}{|c|}{ Research period } & \multirow{2}{*}{$\begin{array}{c}\text { Annual loss } \\
\text { of humus, } \\
\text { t/ha }\end{array}$} \\
\cline { 2 - 4 } & $\begin{array}{c}\mathbf{1 9 6 8}- \\
\mathbf{1 9 9 0}\end{array}$ & $\mathbf{1 9 9 0 - 2 0 0 6}$ & $\mathbf{2 0 0 6 - 2 0 1 7}$ & -0.86 \\
\hline $20-50$ & -21 & -22 & -11 & -0.12 \\
\hline $50-100$ & -9 & 2 & 1 & 0.18 \\
\hline $0-100$ & -22 & 1 & 0 & -0.8 \\
\hline
\end{tabular}

The cause of loss of humus in the top layers is increased mineralization of humus and plant residues when the topsoil is plowed. In addition, its migration deep down is observed, due to changes in qualitative composition of humus and its increased mobility.

Deterioration of humus state of leached chernozem continued during its subsequent plowing for 16 years. Humus reserves in a one meter layer diminished from 459 yo $440 \mathrm{t} / \mathrm{ha}$ in a period from 1990 to 2006 . It is worth noting that there were no changes in the $50-100 \mathrm{~cm}$ layer during this period. The last 12 years (2006-2018) are characterized with a minimal reduction in humus reserves. Its losses amounted to $10.6 \mathrm{t} / \mathrm{ha}$, of which 1 tonne migrated to the $20-50 \mathrm{~cm}$ layer. Deterioration of the humus state of plowed land happens due to a reduction of its reserves in the $0-20 \mathrm{~cm}$ layer, where maximum changes are observed: a reduction of $22 \mathrm{t} / \mathrm{ha}$ is registered.

Soil reaction plays an important role in agriculture, as many crops have very precise requirements to the soil reaction and quite sensitive to its change. Acidic soils create unfavorable conditions for growth and development of plants, thus leading to a reduced productivity of plowed lands and gradual reduction of soil fertility.

Climatic conditions of Western Siberia predispose for formation of natural acidifying of normal soils. Leaching of alkali earths leads to gradual increase in potential acidity that immediately manifests during the intensive land use under plowing. Multiple studies have proven that agricultural soils of Western Sibera are in the most need of regular chalking, as the processes of leaching and biogenic removal of calcium and magnesium are significantly increased under plow.

Our studies have shown, that during the 22 years of plowing the leached chernozem, exchange acidity of the plowed layer increased from 5.5 to 5.2 units. Further plowing did not stop the acidification either and it reached 5.0 units by 2006. (Fig.2). Later, if there are no serious changes in soil maintenance and fertilizing system, the exchange acidity stabilizes and stays at the same level for a prolonged period of time. Increase of acidity takes place beyond the plowed layer as well. In 38 years of plowing, exchange acidity in the 30-50 $\mathrm{cm}$ layer increased from 5.3 to 5.1 units. Lower acidifying effect in the plow-pan is determined by vicinity of carbonate horizon, from where calcium carbonate is raised with the ascent of water to the upper layers, thus impeding significant acidification.

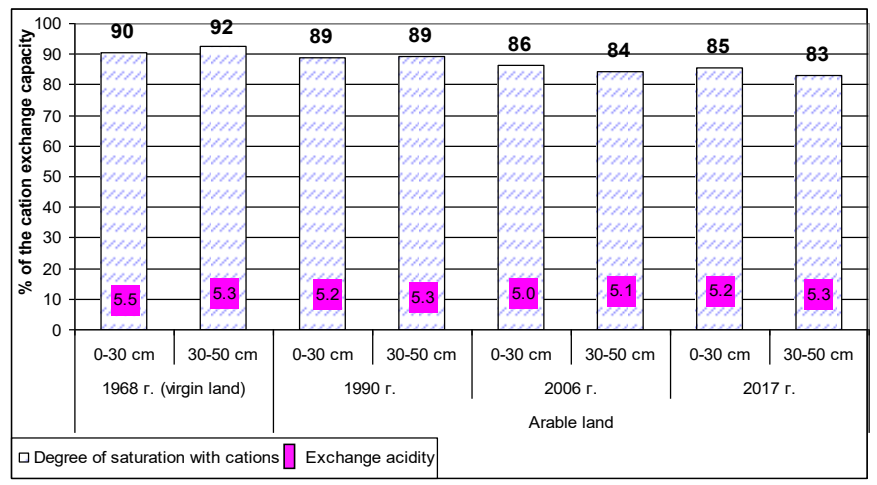

Fig. 2- Dynamics of cation saturation and hydrolytic acidity of plowed chernozem

Analysis of dynamics in total sum of the exchange bases and hydrolytic acidity revealed deeper changes in chemical properties. In 22 years of plowing, the total sum of exchange bases fell from 34.8 to $31.4 \mathrm{mmol} / \mathrm{kg}$ of soil, at that, hydrolytic acidity increased from 3.7 to $3.9 \mathrm{mmol} / \mathrm{kg}$ of soil (Fig. 3). Further plowing of the leached chernozem did not lead to stabilization of its chemical properties and deterioration continued. The chemical degradation process becomes the most evident when comparing the the degree of base saturation, which reached $90-95$ on virgin land, while in the plowed field it is only $80-85 \%$ of the cation exchange volume.

The causes of increased acidity are:

- changes in qualitative composition of humus with formation of a large volumes of fulvic acids;

- biogenic removal of alkali earths cations ( $\mathrm{Ca}$ and $\mathrm{Mg}$ ) with the grown crops;

- $\quad$ increased leaching rate of the above mentioned cations from the soil absorbing complex. 


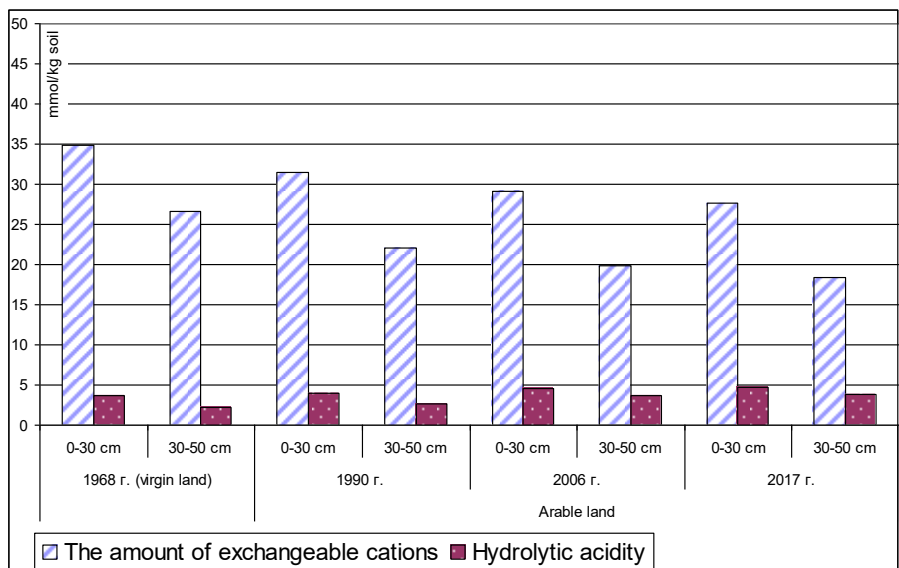

Fig. 3 - Change in the total sum of exchange cations and hydrolytic acidity of plowed chernozem, $\mathrm{mmol} / \mathrm{kg}$ of soil

Another one indicator of soil fertility is cation exchange capacity that indicates the total amount of absorbed actions. Buffer ability of the soil depends on this value. Our calculations have shown that in 1968 the virgin chernozem of the Trans-Ural forest-steppe zone was characterized with a relatively high cation exchange capacity: in the $0-30 \mathrm{~cm}$ layer it reached 38.4, while in the $30-50 \mathrm{~cm}$ layer is was 28.8 $\mathrm{mmol} / \mathrm{kg}$ of soil. After plowing and prolonged use of this chernozem under the plow (22 years), its cation exchange capacity reduced to $35.3 \mathrm{mmol} / \mathrm{kg}$, that is, the reduction amounted to $8.3 \%$ of the initial values. In the $30-50 \mathrm{~cm}$ layer, a $4.0 \%$ reduction of this indicator is registered as well. It should be noted, that during the same 22 years, no statistically reliable changes in cation exchange capacity were registered on the virgin land. After 38 years of annual plowing, this value dropped to 33.7 and $23.5 \mathrm{mmol} / \mathrm{kg}$ respectively. Total reduction amounted to 14 and $23 \%$ with respect to the 1968 values. This fact indicates that during the first years after plowing virgin or postagrogenic soils, a partial destruction of arable land colloidal component takes place, which subsequently slows down. It is supported with the values for the year 2017, where there is a minimal deviation from the values obtained in 2006 .

Another fact shall be noted: agrogenic changes take place not only in the plowed layer $(0-30 \mathrm{~cm})$, but deeper as well. At that, the $30-50 \mathrm{~cm}$ layer is characterized with a more serious reduction in cation exchange capacity, thus, this layer will undergo a more significant acidification due to its loss of buffer capability.

To prevent destruction of soil colloids that are responsible for absorption capability of soils, a land use system shall be developed in such a way that it ensures annual input of large volumes of plant residues to the soil.

In virgin chernozems the Вк horizon is at a depth of 90$110 \mathrm{~cm}$, while in old-arable lands it is significantly deeper and may be $120-140 \mathrm{~cm}$. A degree of carbonate leaching from the soil profile depends on granulometric composition and intensity of land use. In the fields where grain-grass crop rotation or perennial glasses are used, the wetted depth is limited to a half-meter layer, which does not lead to lowering the boiling line.
Once it was thought that the granulometric composition is conservative, thus, it was practically ignored in agricultural and environmental assessments. However, the modern research has shown that under condition of a prolonged action of mechanical treatment of soil with farming implements, an in-profile redistribution of granulometric composition takes place [17]

Our research has shown that at the virgin plot the physical clay content is $42.5-43.7 \%$ in the humus accumulation horizon, while in deeper layers this indicator reaches $50.3 \%$. This is an evidence of profile differentiation in leached chernozem and establishment of an illuvial horizon there. It is caused by appearance of contemporary migration of silt particles without destruction.

From 1968 to 2012, no changes in physical clay distribution through the profile were registered for the virgin plot. All deviations were within the margin of error and amounted to $0.1-0.9 \%$ of the initial values.

Plowing of virgin chernozem and its prolonged use under plow led to redistribution of the physical clay through the soil profile. During the years of studies, the plowed layer $(0-20 \mathrm{~cm})$ lost $2.3-3.1 \%$ of its physical clay due to mechanical treatment and changes in agrophysical indicators (bulk density and structural aggregate composition), which led to increased water permeability and appearance of cracks that subsequently are filled with fine earth. In total, these factors caused redistribution of the physical clay through the soil profile.

Accumulation of particles under $0.01 \mathrm{~mm}$ in the $30-40 \mathrm{~cm}$ layer is determined by migration of fine dust $(0.05-0.001 \mathrm{~mm})$, which is of low dispersion ability and prone to coagulation. When its content increases, the water permeability of the horizon reduces due to high swellability and contractability; at that, both stickiness and bulk density increase. Medium dust fraction $(0.01-0.005 \mathrm{~mm})$ underwent migration as well, but only to a limited depth. Larger fractions did not move through the profile.

Plowed chernozems are characterized with a lower content of silt fraction in the upper layers of the humus horizon as compared to their virgin analogs. As it was established, medium and fine dust fractions are accumulated directly under the plowed layer and actively participate in formation of the plow pan. Silt particles penetrate to deeper layers $(60-90 \mathrm{~cm})$, significantly changing hydrophysical and physical-mechanical properties of the plowed chernozems.

\section{CONCLUSION}

Plowing of leached chernozem is characterized with an abrupt reduction in the mass of plant residues, which leads to reduction of humus reserves not only in the plowed layer, but in underlying layers as well. During 1968-1990, humus reserves of leached chernozem reduced by 22 tonnes $(4.6 \%$ of initial reserves), the dehumification rate was $1.0 \mathrm{t} /$ year. During the subsequent 16 years, humus reserves reduced by $19 \mathrm{t} / \mathrm{ha}$ and attained 440 in one meter layer by 2006 . Prolonged agricultural use of leached chernozems amplifies processes of leaching and biogenic removal of calcium and magnesium, which in the conditions of Trans-Ural forest-steppe zone leads 
to increased exchange and hydrolytic acidity, from 5.5 units and $3.7 \mathrm{mmol} / \mathrm{kg}$ to 5.0 units and $4.6 \mathrm{mmol} / \mathrm{kg}$ respectively. Old-arable leached chernozems have deeper illuvial-carbonate horizon (Вк), down to $120-140 \mathrm{~cm}$, while in the virgin land it is $90-110 \mathrm{~cm}$, and thus ingress of calcium carbonate under the action of ascent of water is virtually impossible.

In plowed leached chernozems, depletion of silt particles in the plowed layer is clearly in evidence, as they migrate to deeper layers, leading to deterioration of agrophysical and hydrophysical properties of the soil.

\section{References}

[1] D.T. Degefie, E. Fleischer, O. Klemm, A.V. Soromotin, O.V. Soromotina, A.V.Tolstikov and N.V. Abramov, "Climate extremes in south western Siberia: past and future" Stoch. Environ. Res. Risk Assess. 28, 2014, pp. 2161-2173. DOI: 10.1007/s00477-014-0872-9.

[2] I. Kuhling, D. Redozubov, G. Broll and D. Trautz, "Impact of tillage, seeding rate and seeding depth on soil moisture and dryland spring wheat yield in Western Siberia", Soil \& Tillage Research, 2017, 170, pp. 43-52. DOI: 10.1016/j.still.2017.02.009

[3] A. Lyubimova and D. Eremin, "Laboratory varietal control as a guarantee of successful work of gribusiness in Russia," [MATEC Web of Conferences, 170, 2018, pp. 04015] https://doi.org/10.1051/matecconf/201817004015

[4] M.A. Chasovshchikova, O.M. Sheveleva, M.A. Svjazhenina, N.I. Tatarkina, A.V. Satkeeva, A.A. Bakharev, E.A. Ponomareva and A.G. Koshchaev, "Relationship between the genetic variants of kappa-casein and prolactin and the productive-biological characteristics of cows of the black-motley breed," Journal of Pharmaceutical Sciences and Research, 9, 2017, pp. 1038-1044.

[5] D. Eremina, "IT-technologies in soil Informatics and Russian agribusiness," [MATEC Web of Conferences. 170, 2018, pp. 04016] DOI: https://doi.org/10.1051/matecconf/201817004016

[6] D. Eremina, "The impact of transport infrastructure on ecological status of arable land in Western Siberia," [MATEC Web of Conferences. 170, 2018, pp. 05004]. https://doi.org/10.1051/matecconf/201817005004

[7] A.V. Iglovikov, "The development of artificial Phytocenosis in Environmental Construction in the far North", Procedia Engineering, 165, 2016, pp. 800-805. DOI:10.1016/j.proeng.2016.11.778.
[8] D.I. Eremin, "The use of modern data about the composition and properties of soil for the development of transport infrastructure of Tyumen", [IOP Conference Series: Earth and Environmental Science, 2017, vol. 90, Conf. 1]. DOI: org/10.1088/1755-1315/90/1/012021.

[9] D.I. Eremin, "Changes in the content and quality of humus in leached chernozems of the Trans-Ural forest-steppe zone under the impact of their agricultural use", Eurasian soil science, 2016, 5, pp. 538-545. DOI: $10.1134 / \mathrm{S} 1064229316050033$

[10] D.I. Eremin and N. A. Gruzdeva, "Influence of anthropogenic factor on microaggregate composition of gray forest soils," Siberian Bulletin of agricultural science, 1,2018 , pp. 28-37. DOI: $10.26898 / 0370-8799-$ 2018-1-4

[11] L. Skipin, E. Zakharova, E. Gaevya V. Burlaenko and A. Mitrikovskiy "Radiation and Geochemical Assessment of the Soil State in the South of Tyumen Region," [MATEC Web of Conferences 73, 2016, pp. 03009]. DOI: https://doi.org/10.1051/matecconf/20167303009

[12] V.A. Korolev, A.I. Gromovik and O.K. Borontov, "Change in the fertility of $\mathrm{s}$ leached chernozem under different primary tillage technologies", Eurasian soil science, 1, 2016, pp. 95-101. DOI: $10.1134 / \mathrm{S} 1064229316010099$

[13] O. Kalinina, S.E. Krause, L. Giani, S.V. Goryachkin, N.A. Karavaeva and D.I. Lyuri, "Self-restoration of post-agrogenic chernozems of Russia: soil development, carbon stocks and dynamics of carbon pools," Geoderma, 1-2, 2011, pp. 196-206.

[14] I. Kurganova, V. Lopes de Gerenyu, Y. Kuzyakov and J. Six, "Carbon cost of collective farming collapse in Russia", Global change biology 3 , 2014, pp. 938-947. DOI: $10.1111 /$ gcb. 12379

[15] O. Kalinina, L. Giani, S.V. Goryachkin and D.I. Lyuri, "Post-agrogenic development of vegetation, soils, and carbon stocks under selfrestoration in different climatic zones of European Russia," Catena. 129, 2015, pp. 18-29. DOI: 10.1016/j.catena.2015.02.016

[16] C. Alcantara, T. Kuemmerle, P. Griffiths, P. Hostert, J. Knorn, D. Müller and A. Sieber, "Mapping the extent of Abandoned farmland in central and eastern Europe using modis time series satellite data", Environmental Research Letters, 3, 2013, P. 035035 . DOI: $10.1088 / 1748-9326 / 8 / 3 / 035035$

[17] N. Ustinov, A. Maratkanov and A. Martynenko, "Experimental study of the parameters of the active tool of a cultivator with a frame in form a flexible tubular element," [MATEC Web of Conferences, 106, 2017, pp. 08063]. DOI: https://doi.org/10.1051/matecconf/201710608063 